\title{
The Unfavourable Impact of Street Traffic on Water Distribution Pipelines
}

\author{
Ioan Așchilean ${ }^{1,2}$ (D), Mihai Iliescu ${ }^{2}$, Nicolae Ciont ${ }^{2}$ (D) and Ioan Giurca ${ }^{3, *}$ (1) \\ SC ACI Cluj SA, 70 Dorobanţilor Avenue, 400609 Cluj-Napoca, Romania; aschileanioan@gmail.com \\ 2 Faculty of Civil Engineering, Technical University of Cluj-Napoca, 15 C-tin Daicoviciu Street, \\ 400020 Cluj-Napoca, Romania; Mihai.Iliescu@cfdp.utcluj.ro (M.I.); Nicolae.Ciont@cfdp.utcluj.ro (N.C.) \\ 3 Faculty of Building Services Engineering, Technical University of Cluj-Napoca, 128-130 21 Decembrie \\ Boulevard, 400604 Cluj-Napoca, Romania \\ * Correspondence: giurca_ioan@yahoo.com; Tel.: +40-072-337-1760
}

Received: 27 July 2018; Accepted: 13 August 2018; Published: 15 August 2018

\begin{abstract}
This article analyses the relation between the failures that occurred in the water supply network and the road traffic in the city of Cluj-Napoca in Romania. The calculations in this case study were made using the Autodesk Robot Structural Analysis Professional 2011 software. In the case study, the following types of pipes were analysed: steel, gray cast iron, ductile cast iron and high density polyethylene (HDPE). While in most studies only a few sections of pipelines, several types of pipelines and certain mounting depths have been analysed, the case study presented analyses the entire water supply system of a city with a population of 324,576 inhabitants, whose water supply system has a length of $479 \mathrm{~km}$. The results of the research are useful in the design phase of water distribution networks, so depending on the type of pipe material, the minimum depth of installation can be indicated, so as to avoid the failure of the pipes due to road traffic. From this perspective, similar studies could also be carried out regarding the negative influence of road traffic on sewerage networks, gas networks and heating networks.
\end{abstract}

Keywords: deterioration; pipeline breaking; pipe failure; street traffic; water distribution networks

\section{Introduction}

\subsection{Context}

The pipelines of water distribution systems must withstand ground loading, groundwater loading and road traffic loading. In this case, the pipeline is treated as a structure as well as a fluid transport pipe and it is designed to fulfil these two functions throughout its lifetime [1].

The frequency of breakage and failure of pipes in water distribution networks is increased over time mainly due to deterioration; when pipes deteriorate, the operation and maintenance costs typically increase, and the hydraulic network capacity and the quality of service decrease [2].

Al-Aghbar [3] stated that the four main reasons for the deterioration of the water distribution networks are:

- the aging of water distribution infrastructure due to environmental factors;

- inadequate preventive maintenance and asset management programmes;

- inappropriate funds and changed municipal priorities;

- lack of information and staff. 


\subsection{Literature Review}

During the construction and service period, pipes must support pressures from soil and vehicle loads applied at the soil surface [4].

$\mathrm{Xu}$ et al. [5] conducted a study on the influence of road load on a reinforced concrete pipe with an inner diameter of $1400 \mathrm{~mm}$, and the study showed that the unfavourable influence of road load depends on the pipe mounting depth.

Li et al. [6] conducted a study analysing the relationship between non-hydraulic factors and pipe failures. Thus, the following factors were taken into account: the type of material from which the pipes are made, the diameter of the pipeline and the types of materials used for the roads in the urban environment. The types of pipes used in the water distribution system were the following: galvanized pipes, glass fibre reinforced polymer (GFRP) pipes, polyethylene (PE), other plastics, ductile cast iron, gray cast iron, steel, multi-layer steel-plastic pipe and concrete pipes. Following the study, the authors concluded that most of the faults occur in the area of concreted roads, these failures being caused by road traffic.

Alzabeebee et al. [7] state that the scholarly literature does not provide clear conclusions about the effect of the pipe diameter and pipe mounting depth on the pipeline behaviour, and that most studies have focused on certain types of pipes, certain pipe diameters and certain pipe mounting depths. So they conducted a study on the effect of pipe diameter and pipe mounting depth; the study was conducted for rigid concrete pipes and flexible PVC pipes, and the traffic loads were considered to be those specified in BS 9295/2010 [8]. The study showed that the effect of road traffic loading becomes insignificant for a pipe mounting depth exceeding $2 \mathrm{~m}$ for concrete pipes and $3 \mathrm{~m}$ for PVC pipes, respectively.

Rajeev et al. [9] conducted a study on large diameter pipeline defects, and the study showed that most of the failures occurred in the case of steel pipes, cast iron pipes and ductile cast iron pipes. Among the causes of defects the authors identified corrosion, water pressure in pipelines, as well as road traffic.

Pislarasu et al. [10] presented a nomogram on establishing the thickness of the pipe wall in the case of steel pipes used in a water supply system, the pipes being mounted buried at depths of $1 \mathrm{~m}$ and $7 \mathrm{~m}$ and the pipes having a diameter between $500 \mathrm{~mm}$ and $1400 \mathrm{~mm}$. The nomogram was drawn up for mobile loads, namely $10 \mathrm{t}$ trucks, as well as for $30 \mathrm{t}$ tracked vehicles.

In the paper [11], a graph on the minimum depth and maximum depth of the ductile iron pipe mounting is presented by a pipeline manufacturer. The graph is designed for pipes with a diameter of $700 \mathrm{~mm}$ and for pipes with a diameter of $2000 \mathrm{~mm}$, and the recommended mounting depth is between $0.8 \mathrm{~m}$ and $7 \mathrm{~m}$-the depth recommended according to the pipe diameter and the pipe nominal pressure.

\subsection{Purpose and Contributions of the Paper}

This study seeks to analyse the impact of street road traffic on water distribution network pipelines.

The necessity of this study results from the critical analysis of the scholarly literature on the impact of street road traffic on water distribution pipelines. Currently used water network failure patterns commonly take into account the characteristics of the pipes, but they often overlook the impact of road traffic. The need to make calculations about the impact of street traffic on pipelines in the local water supply systems arises from the fact that pipeline manufacturers usually indicate the minimum and maximum pipe mounting depths for only certain road traffic loads and for certain calculation hypotheses, and in practice, both road traffic loads and other calculation hypotheses can vary considerably.

The results of the research are useful on the one hand in the phase of water distribution networks design and on the other hand in the phase of water distribution networks exploitation. 


\section{Materials and Methods}

\subsection{Studied Area}

This article analyses the relation between the failures in the water supply network and the road traffic in the case of the city of Cluj-Napoca, Romania. Following the field inventory of existing pipeline types, it was concluded that the water distribution network of the city of Cluj-Napoca has a length of $479 \mathrm{~km}$ and serves 324,576 inhabitants.

The paper represents a continuation of the research conducted by the authors within a doctoral thesis [12], as well as within a research grant [13].

Figure 1 shows the annual evolution of the number of failures in the water supply network of the city of Cluj-Napoca, by connecting pipes, by distribution pipes (DN 80-400 mm), by lanes (DN 400-600 mm) and by adductions (DN 600-1400 mm); the analysis period being the years 2002-2010.

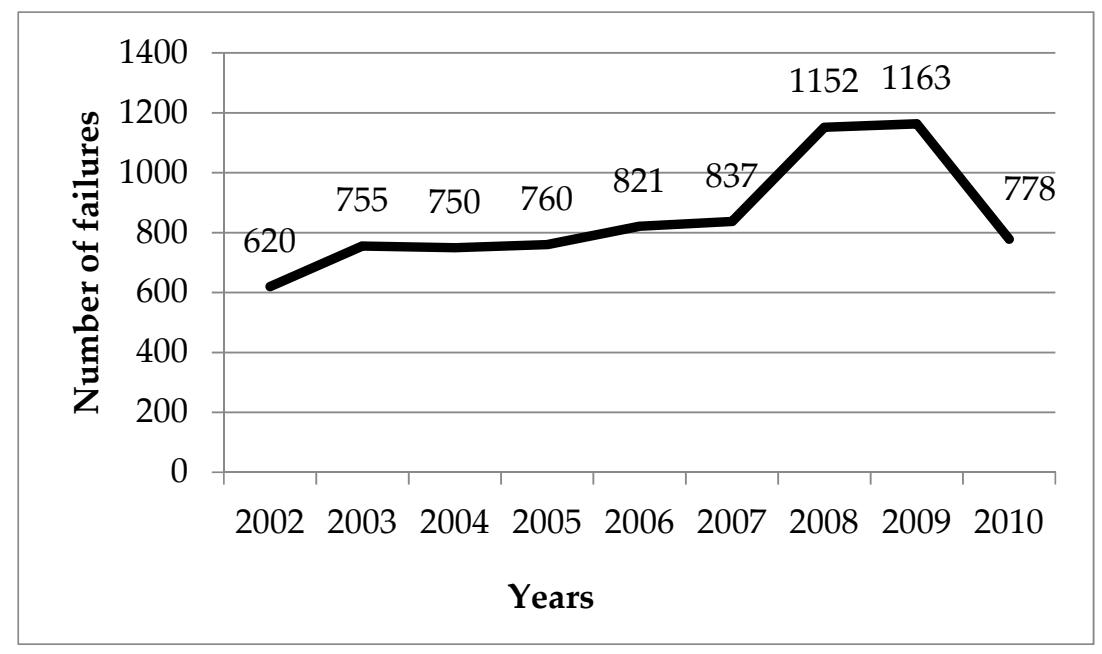

Figure 1. The annual evolution of the number of failures occurred in the water supply network of Cluj-Napoca during 2002-2010 [14].

An analysis of the data in Figure 1 reveals that the number of water supply network failures in the city of Cluj-Napoca increased by 37\% in 2008 compared to 2007 and increased continuously until 2009. We mention that the road system in the city of Cluj-Napoca was rehabilitated and modernized during the period 2007-2009. Figure 1 shows that in 2010 the number of failures in the water supply network in Cluj-Napoca decreased, due to the fact that in 2009 the road system rehabilitation process was completed.

Figure 2 shows the monthly evolution of failures in the water supply network of the city of Cluj-Napoca for the period February 2007-December 2009. 


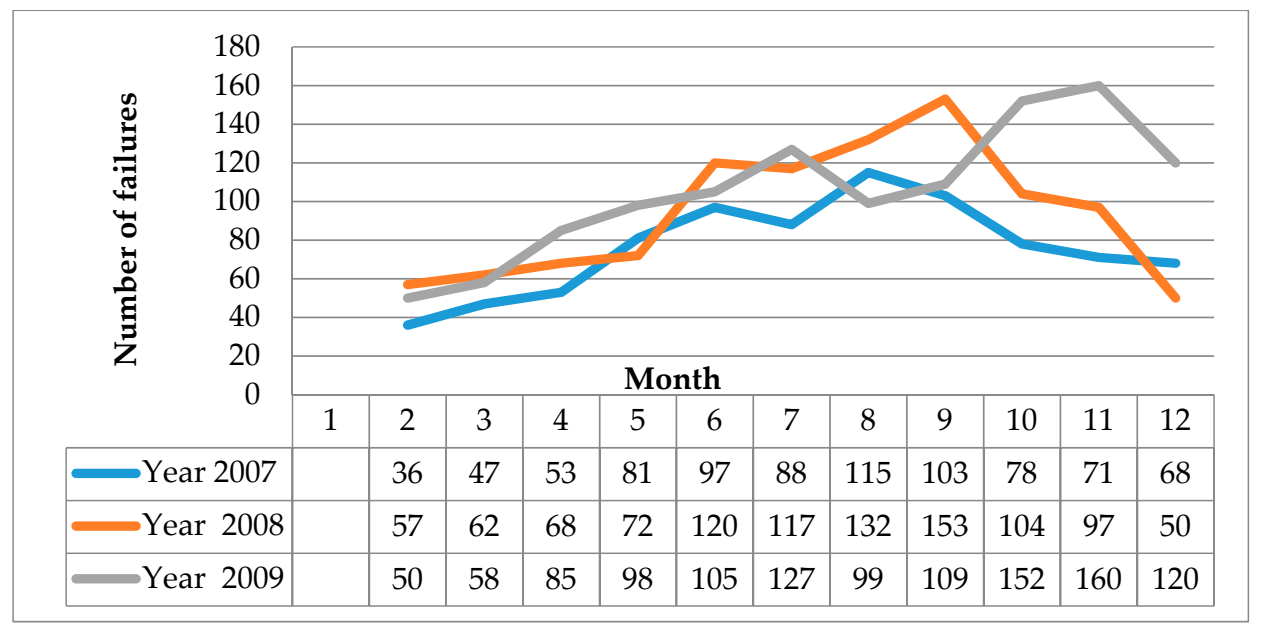

Figure 2. Monthly evolution of failures that occurred in the water supply network of Cluj-Napoca, February 2007-December 2009 [14].

Most pipelines for the water supply system of Cluj-Napoca are located under the road system, and repairs to the road system in Cluj-Napoca are usually carried out from April-December. Analysing the data in Figure 2, it can be noticed that the number of failures increased in the water supply system during the period from May to October, so there is a correlation between the number of failures in the water supply system of the city of Cluj-Napoca and the period to carry out repairs to the road system.

\subsection{Materials}

\subsubsection{Materials Used for Building the Water Distribution Networks}

Over time, several types of materials were used for making the pipes of the water supply systems. It began with the stone and wood, continued with prefabricated wooden items (staves), stone (masonry) and bricks (fitted in with lime and then with cement), lead and copper, and during the past 200 years, the iron was used, first in the form of cast iron and afterwards in the form of steel. In the 20th century, the plastics and composite materials industry developed [14-16].

The main materials currently used for water distribution networks are the following: steel, gray cast iron, ductile cast iron, asbestos cement, reinforced concrete, plastics, polyethylene (PE), glass fibre reinforced polymer (GFRP), and other materials [12-26].

A study of the pipeline types used for the 1.5 million km distribution network in The Netherlands, Belgium, Japan, South Africa, Spain, Switzerland, France, Norway, Australia, USA and Germany provides the following data on the share of pipeline types, which are presented in Table 1 [14].

Table 1. Share of water distribution pipelines depending on the pipe diameter and material type [14].

\begin{tabular}{ccccccc}
\hline \multirow{2}{*}{$\begin{array}{c}\text { Pipe Diameter } \\
(\mathbf{m m})\end{array}$} & $\begin{array}{c}\text { Plastics } \\
\mathbf{( \% )}\end{array}$ & $\begin{array}{c}\text { Concrete } \\
\mathbf{( \% )}\end{array}$ & $\begin{array}{c}\text { Asbestos } \\
\text { Cement } \mathbf{( \% )}\end{array}$ & $\begin{array}{c}\text { Cast Iron } \\
\mathbf{( \% )}\end{array}$ & $\begin{array}{c}\text { Steel (\%) } \\
\text { (\%) }\end{array}$ & $\begin{array}{c}\text { Other Materials } \\
(\%)\end{array}$ \\
\hline$<200$ & 29.2 & 0.1 & 24.7 & 40.6 & 4.4 & 1 \\
$200-400$ & 17.9 & 0.4 & 15.2 & 56.6 & 4.6 & 5.3 \\
$>400$ & 0 & 8.4 & 8.2 & 64.2 & 19.2 & 0 \\
\hline
\end{tabular}

Following the analysis of data in Table 1, it can be noticed that one of the most used materials for building the water distribution networks was cast iron. Also, for pipes with a diameter under $400 \mathrm{~mm}$, the plastics are ranked second place.

In the United States, the reason why cast iron was the most used material is because most of the water distribution system was built during the Second World War and good quality pipe materials 
were not quite available during the war. Due to this fact, a large number of cheaper and lower quality pipes [27] were used for the water distribution system.

This may also explain the increasing use of new materials, such as PVC and PE, for water distribution networks [22].

Gray cast iron and ductile cast iron represent more than two-thirds of the length of existing water networks in Canada. Steel, polyvinyl chloride (PVC), high density polyethylene (HDPE), asbestos cement and concrete pressure pipe (CPP) are also used for Canada water pipelines [28].

As a result of the analysis carried out by the Romanian Water Association, 30\% of the length of the water distribution networks in Romania was found to be represented by steel pipes (see Table 2) [29].

Table 2. Romanian water distribution pipelines [29].

\begin{tabular}{ccc}
\hline Pipeline Material & Length $\mathbf{( k m )}$ & Percent out of the Total Length $\mathbf{( \% )}$ \\
\hline Plastics & 390 & 1 \\
Concrete pressure pipe (CPP) & 779 & 2 \\
Gray cast iron & 818 & 21 \\
Steel & 11,686 & 30 \\
Asbestos cement & 17,918 & 46 \\
\hline
\end{tabular}

\subsubsection{Road Traffic and Road Types inside Urban Areas}

Among the main defects affecting the components of a water distribution network are also pipe cracks and breaks or other constituents. One of the causes that leads to these defects is represented by external loadings that affect the constituents of the network.

The occurrence of defects as a result of the action of external factors (road traffic, works, earthworks, etc.) leads to chained effects, which include:

- $\quad$ road structure damage;

- possible dangers to the lives and safety of citizens;

- interruptions of utility supply to the population and businesses;

- additional costs etc.

Nowadays, many streets and urban networks are undergoing rehabilitation and modernization processes. This is accompanied by an increase in the volume of road traffic and of the direct loading of vehicles. Consequently, the problem that arises is the avoidance of the occurrence of defects in the underground networks, caused by road traffic. At the same time, it is intended to optimize the process of modernization and rehabilitation of urban networks, so as to minimize the possibility of failure of the network constituents.

As a result, studying the unfavourable impact of street road traffic on water distribution pipelines and analysing possible solutions respond to the need of eliminating defects arising from the above-mentioned causes and affecting water distribution networks.

According to the Romanian laws [30], the streets are public roads inside the localities, arranged specifically for:

- vehicle and pedestrian circulation;

- placement of technical and municipal networks;

- ensuring access to adjacent buildings.

According to the Romanian laws [31,32], there are four categories of streets, having the geometrical characteristics of the standard cross-sectional profile presented in Table 3. 
Table 3. Streets-geometrical constituents in cross-sectional profile [31,32].

\begin{tabular}{cccc}
\hline Street Category & Number of Lanes & Lane Width $(\mathbf{m})$ & Roadway Width $(\mathbf{m})$ \\
\hline I & 6 & 3.50 & 21.00 \\
II & 4 & 3.50 & 14.00 \\
III & 2 & $3.00 ; 3.50$ & $6.00 ; 7.00$ \\
IV & 1 & $3.00 ; 3.50$ & $3.00 ; 3.50$ \\
\hline
\end{tabular}

Obviously, the most intense traffic is in the case of the streets from the 1st category. The main types of road structures that can be used for streets are:

- $\quad$ flexible road structures;

- $\quad$ rigid road structures;

- road structures with carved stone paving carpets;

- road structures with self-locking concrete paving carpets;

- road structures with crushed stone surface, macadam, penetrated macadam carpets;

- pavement of rough stone or cobble (recommended for streets in rural areas).

\subsection{Methods}

In this study, we are trying to determine the unitary stresses that take place in the walls of the pipelines of the water distribution networks, under the pressure of road traffic and filler earth.

The software used to run the computations in this case study was Autodesk Robot Structural Analysis Professional 2011 [33]. This is a program for calculation by finite element structures that includes a wide range of design codes of all types of metal and concrete structures, with the possibility of contemplating other structural materials [34].

Two basic hypotheses are considered in the calculation:

- $\quad$ pipeline in initial state, in ground free of groundwater;

- $\quad$ pipeline in running order, in ground with groundwater.

The general calculation model used in order to assess the loadings on the water distribution networks is presented in Figure 3.

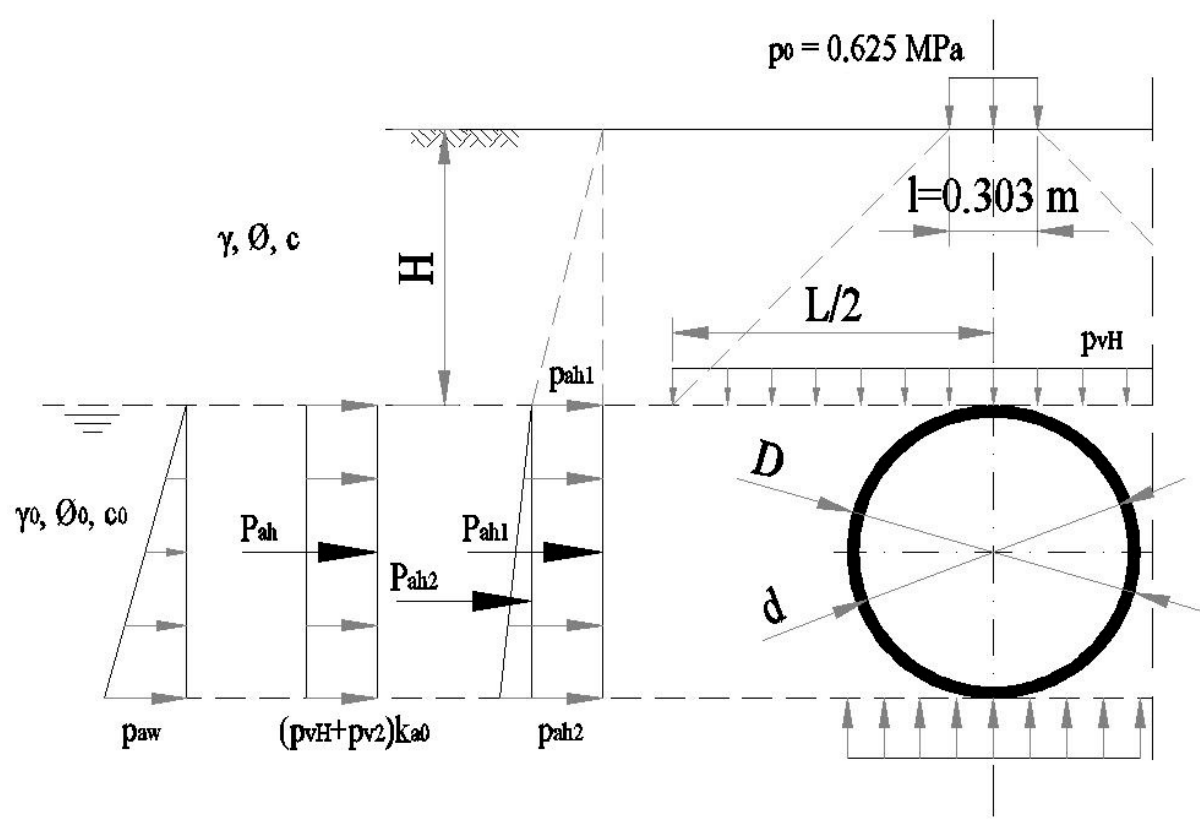

Figure 3. Pipeline loadings calculation model. 
The meanings of the terms are the following:

\begin{tabular}{|c|c|}
\hline $\mathrm{p}_{0}$ & uniformly distributed pressure from the standard semi-axle; \\
\hline 1 & width of the indentation of the standard semi-axle $(1=303 \mathrm{~mm})$; \\
\hline $\mathrm{H}$ & pipe coverage thickness/overlay + road structure thickness; \\
\hline $\mathrm{L}$ & distributed width of the indentation of the standard semi-axle; \\
\hline $\mathrm{D}$ & outer pipe diameter; \\
\hline$\gamma$ & volumetric weight of the filler earth above the pipe/pipe overlay density; \\
\hline$\varnothing$ & internal friction angle of the filler earth above the pipe; \\
\hline c & cohesion of the filler earth above the pipe; \\
\hline $\mathrm{ka}, \mathrm{k}_{0}$ & coefficient of lateral earth pressure; \\
\hline$\gamma_{0}$ & volumetric weight of the filler earth around the pipe; \\
\hline$\varnothing_{0}$ & internal friction angle of the filler earth around the pipe; \\
\hline $\mathrm{c}_{0}$ & cohesion of the filler earth around the pipe; \\
\hline pvH & uniformly distributed vertical pressure from the standard semi-axle at depth $\mathrm{H}$ and $45^{\circ}$; \\
\hline pv2 & uniformly distributed loading from the filler earth at depth $\mathrm{H}$; \\
\hline pah1, pah2 & active compression of the earth on the pipe's height; \\
\hline $\begin{array}{l}\text { Pah1, Pah2, Pah } \\
\text { paw }\end{array}$ & $\begin{array}{l}\text { resultants of the active compression of earth on the pipe's height; } \\
\text { underground water lateral pressure. }\end{array}$ \\
\hline
\end{tabular}

In Romania, the standard vehicle axle load is $115 \mathrm{kN}$, as stated in Reference [35]. In the considered model, a local force representing a standard semi-axle load was applied. The real tyre-pavement contact surface is elliptical. However, the PD 177 standard [36] states that it may be considered circular, with a radius of $171 \mathrm{~mm}$ and an applied uniform load $\mathrm{p}_{0}=0.625 \mathrm{MPa}$. For model convenience, the contact surface was modelled as a $303 \times 303 \mathrm{~mm}$ square, with the same applied load.

The pressure $\mathrm{p}_{0}$ of the standard semi-axle was assessed by equivalence of the $57.5 \mathrm{kN}$ concentrated force with the loading distributed on the contour of a square surface having the side $1=30.3 \mathrm{~cm}$ [36]. Thus it results $\mathrm{p}_{0}=0.625 \mathrm{MPa}$.

Considering that each layer of a road structure has a well-defined role, it has been studied how the road traffic loadings are distributed on the thickness of the road system. Thus, we made a calculation model consisting of a plate on elastic medium having the area of $1 \mathrm{~m}^{2}$ and the deformability characteristics presented in Table 4, centrically and vertically stressed with a concentrated force $\mathrm{F}=57.5 \mathrm{kN}$.

As this study focuses on the impact of street traffic on water distribution pipelines, a common flexible road structure, modelled as a multi-layer system, was considered (v. Table 4). The design of such non-rigid pavements may be carried out using an analytical method, which consists of analysing the state of stresses and strains in the configured pavement, under the standard semi-axle load, using the Burmister model for different cases of multi-layered systems [37].

The calculation model for the plate is presented in Figure 4.

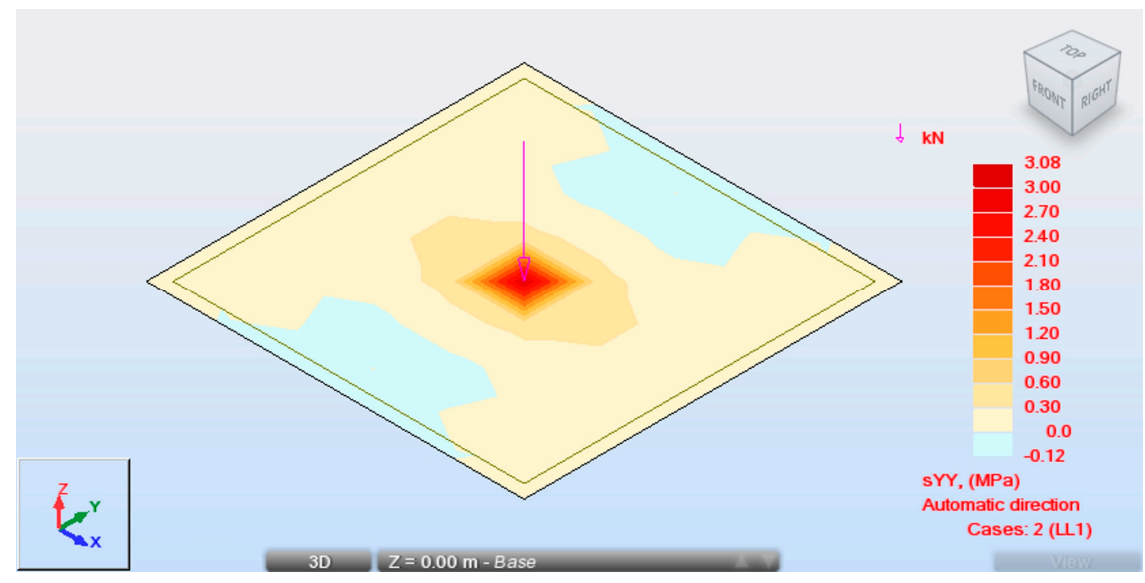

Figure 4. Plate calculation model. 
Thus, a distribution of the stresses on the road structure thickness similar with the one presented in Figure 5 is obtained.

Table 4. Characteristics of the materials composing the flexible road structure.

\begin{tabular}{ccc}
\hline Material & Dynamic Elasticity Modulus E (MPa) & Poisson's Ratio $\mu$ \\
\hline Asphalt mixture-wearing course & 3600 & 0.35 \\
Asphalt mixture-binder course & 3000 & 0.35 \\
Asphalt mixture-base course & 5000 & 0.35 \\
Intermediate aggregate-optimal & 500 & 0.27 \\
mixture & 300 & 0.27 \\
Ballast &
\end{tabular}

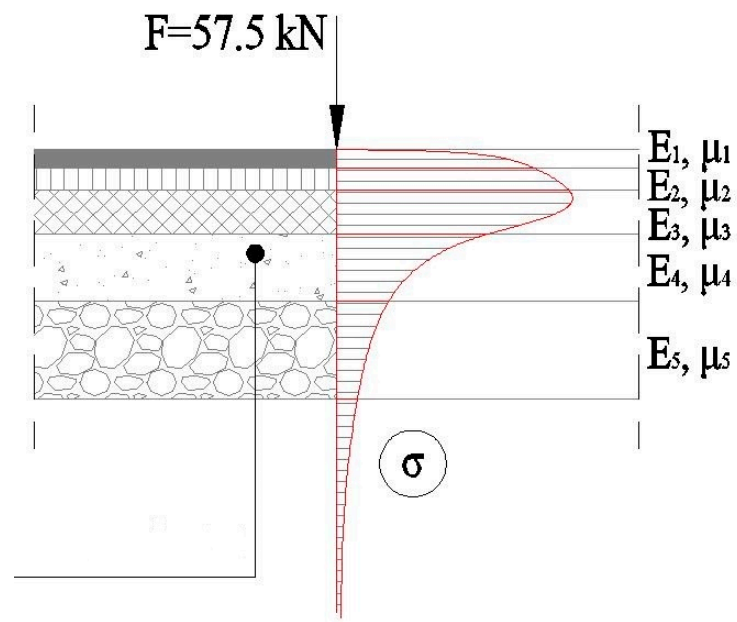

Figure 5. Distribution of stresses on the thickness of the road structure.

Considering a modernized street with a non-rigid road structure on the route of which water distribution networks are disposed, the distribution of road traffic loadings is therefore decreasing with the depth. The maximum values of stresses generated by road traffic are recorded at depths of $10-25 \mathrm{~cm}$ from the surface of the wear layer. Thus, the essential structural role of the base course in a road system is justified.

Numerous defects of underground public networks occur during and following repair, rehabilitation or street modernization works, due to the reduction of piping coverage and the heavy machinery used in road works [12].

Thus, it should be considered the situation where the piping coverage is reduced to the minimum and significant dynamic actions are recorded. According to European standards [38], it is recommended to multiply the characteristic values of actions with dynamic coefficients with values up to 2 .

This study considers a distribution to $45^{\circ}$ of the uniformly distributed load from the standard semi-axle through the filler earth above the pipelines; a hypothesis which includes cases where road works are being carried out on the streets in question.

If groundwater is present, when assessing the earth compression, we took into account the density of the earth in submerged state as well as the hydrostatic pressure of the groundwater. At the same time, assuming that the water supply pipes are functional and full, the filler earth is subjected to a stress by the pipe's walls. Thus, the earth compression is considered as passive.

The earth active compression ratios were assessed using the Rankine theory:

$$
\begin{gathered}
\mathrm{ka}=\operatorname{tg}^{2}\left(45^{\circ}-\varnothing / 2\right), \\
\mathrm{ka}_{0}=\operatorname{tg}^{2}\left(45^{\circ}-\varnothing_{0} / 2\right),
\end{gathered}
$$


Similarly, the ratios of the earth passive compression were assessed:

$$
\begin{gathered}
\mathrm{kp}=\operatorname{tg}^{2}\left(45^{\circ}-\varnothing / 2\right), \\
\mathrm{kp}_{0}=\operatorname{tg}^{2}\left(45^{\circ}-\varnothing_{0} / 2\right),
\end{gathered}
$$

As a result of the comparative study of the calculation hypotheses, it was concluded that the maximum loadings arise when the pipes are filled with water and the filler earth exerts passive pressure on the walls of the pipelines.

To evaluate the stress, we grouped the actions according to the following formula [39]:

$$
\mathrm{Ed}=\gamma \mathrm{G} \cdot \mathrm{Gk}+\gamma \mathrm{P} \cdot \Phi \cdot \alpha \mathrm{P} \cdot \mathrm{Pk}+\alpha \mathrm{Q} \cdot(\gamma \mathrm{Q} 1 \cdot \mathrm{Qk} 1+\gamma \mathrm{Q} 2 \cdot \mathrm{Qk} 2),
$$

where:

Ed calculation value of the effect of the actions;

Gk characteristic value of the permanent actions (own weight);

$\mathrm{Pk} \quad$ characteristic value of the temporary action of the road traffic;

Qk1 characteristic value of the permanent action from the earth filler;

Qk2 characteristic value of the permanent action from the earth compression;

$\gamma \mathrm{G} \quad$ partial ratio for permanent actions (own weight); $\gamma \mathrm{G}=1.35$;

$\gamma \mathrm{P} \quad$ partial ratio for the temporary action of the road traffic; $\gamma \mathrm{P}=1.35$;

$\gamma \mathrm{Q} 1 \quad$ partial ratio for the permanent actions from the earth filler; $\gamma \mathrm{Q} 1=1.35$;

$\gamma$ Q2 partial ratio for the permanent actions from the earth compression; $\gamma \mathrm{Q} 2=1.00$;

$\Phi$ dynamic ratio for the temporary action of the road traffic (see Table 5);

$\alpha \mathrm{P}, \alpha \mathrm{Q} \quad$ heavy traffic loading factors; $\alpha \mathrm{P}=\alpha \mathrm{Q}=1.10$.

Table 5. Adopted values of the dynamic ratio $\Phi$.

\begin{tabular}{cc}
\hline H Pipe Coverage Thickness $(\mathbf{m})$ & Dynamic Ratio $\mathbf{\Phi}$ \\
\hline$\leq 0.50$ & 2.00 \\
$0.60-0.90$ & 1.80 \\
$1.00-1.50$ & 1.50 \\
$1.60-3.00$ & 1.20 \\
$>3.00$ & 1.00 \\
\hline
\end{tabular}

Thus the following formulas result for the groups of actions (see Table 6):

Table 6. Calculation formulas.

\begin{tabular}{cc}
\hline H Pipe Coverage Thickness $(\mathbf{m})$ & Ed Calculation Formula \\
\hline$\leq 0.50$ & $1.35 \cdot \mathrm{Gk}+3.00 \cdot \mathrm{Pk}+1.50 \cdot \mathrm{Qk} 1+1.10 \cdot \mathrm{Qk} 2$ \\
$0.60-0.90$ & $1.35 \cdot \mathrm{Gk}+2.65 \cdot \mathrm{Pk}+1.50 \cdot \mathrm{Qk} 1+1.10 \cdot \mathrm{Qk} 2$ \\
$1.00-1.50$ & $1.35 \cdot \mathrm{Gk}+2.20 \cdot \mathrm{Pk}+1.50 \cdot \mathrm{Qk} 1+1.10 \cdot \mathrm{Qk} 2$ \\
$1.60-3.00$ & $1.35 \cdot \mathrm{Gk}+1.80 \cdot \mathrm{Pk}+1.50 \cdot \mathrm{Qk} 1+1.10 \cdot \mathrm{Qk} 2$ \\
$>3.00$ & $1.35 \cdot \mathrm{Gk}+1.50 \cdot \mathrm{Pk}+1.50 \cdot \mathrm{Qk} 1+1.10 \cdot \mathrm{Qk} 2$ \\
\hline
\end{tabular}

The stresses were assessed for a selection of pipes used for water distribution networks covering a large range of materials and diameters, as follows:

- $\quad$ round steel pipes: $\varnothing 48.3 \times 2.6 \mathrm{~mm}$; $\varnothing 88.9 \times 3.2 \mathrm{~mm}$; $\varnothing 114.3 \times 4 \mathrm{~mm}$; $\varnothing 168.3 \times 5 \mathrm{~mm}$; $\varnothing 244.5 \times 6.3 \mathrm{~mm}$; Ø $323.9 \times 8 \mathrm{~mm}$; Ø $406 \times 8 \mathrm{~mm}$; $508 \times 10 \mathrm{~mm}$; $610 \times 12.5 \mathrm{~mm}$;

- $\quad$ round (gray and ductile) cast iron pipes: Ø $222 \times 11 \mathrm{~mm}$; Ø $428 \times 14 \mathrm{~mm}$; Ø $634 \times 17 \mathrm{~mm}$; $\varnothing 841 \times 20.5 \mathrm{~mm}$; Ø $1048 \times 24 \mathrm{~mm}$;

- $\quad$ high density polyethylene tubes (HDPE): $\varnothing 20 \times 2 \mathrm{~mm}$; $\varnothing 40 \times 2.4 \mathrm{~mm}$; $\varnothing 75 \times 4.5 \mathrm{~mm}$; $\varnothing 110 \times 6.6 \mathrm{~mm}$ Ø $160 \times 9.5 \mathrm{~mm} ; \varnothing 200 \times 11.9 \mathrm{~mm} ; \varnothing 250 \times 14.8 \mathrm{~mm} ; \varnothing 315 \times 18.7 \mathrm{~mm}$; $\varnothing 400 \times 23.7 \mathrm{~mm}$. 
The technical details regarding the geometrical and physical-mechanical characteristics of the building materials were taken from the catalogues provided by the manufacturers and authorized distributors of these items.

Stresses have been evaluated based on the laying depth of the constituents.

For the automated calculation of the stresses, a calculation model was chosen consisting of a continuous beam with a length of $10 \mathrm{~m}$, supported on elastic supports arranged every $1 \mathrm{~m}$ along the pipe (see Figure 6), uniformly distributed by the assessed load calculations, both horizontally and vertically.

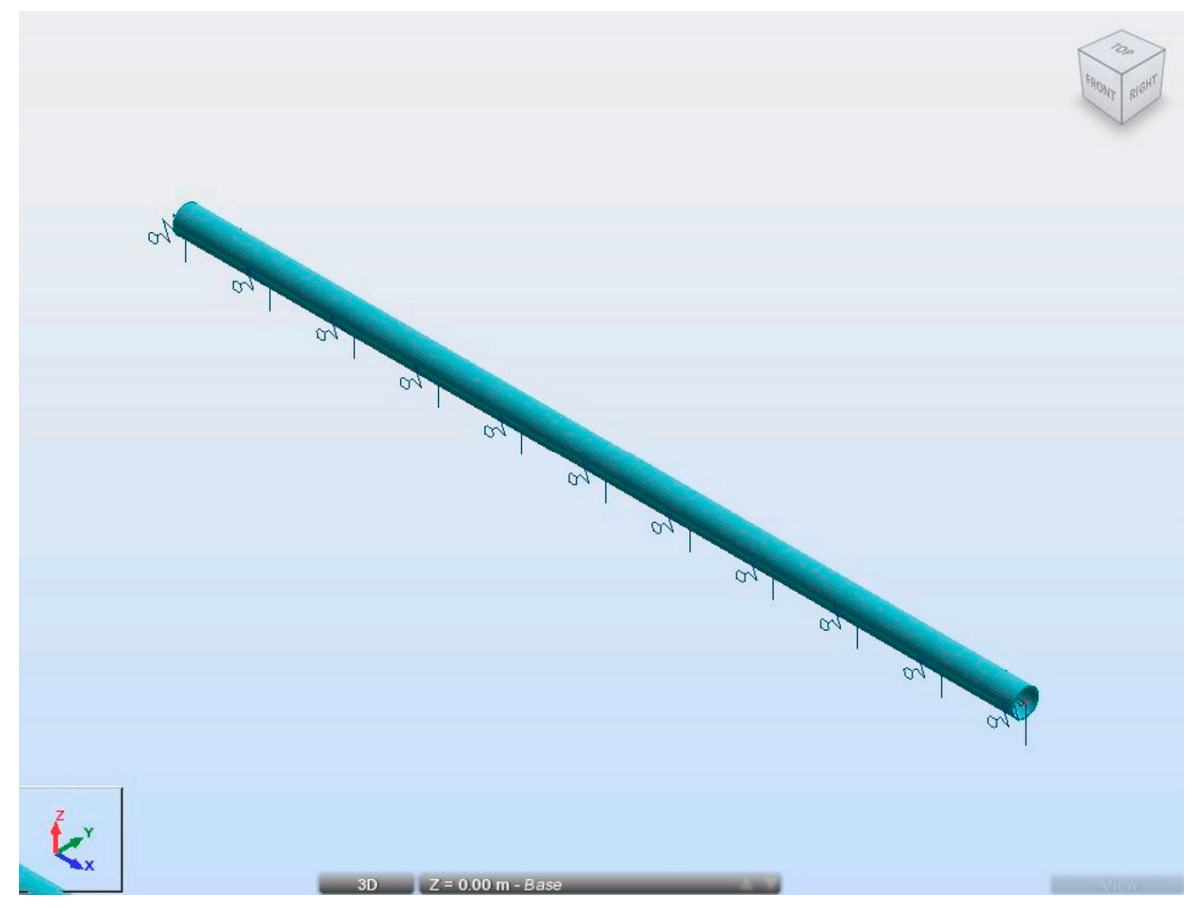

Figure 6. Calculation model for pipes.

\section{Results and Discussions}

\subsection{Results}

In this study, assessments were made on the loadings occurring in the water distribution pipes subject to heavy road traffic. The case study was conducted for heavy traffic conditions in Romania.

The following types of pipes were analysed: steel pipes, gray cast iron pipes, ductile cast iron pipes and high density polyethylene (HDPE) pipes.

\subsubsection{Steel Pipes}

The resistance calculation for the steel pipes was made considering the types of round pipes presented in Table 7 , having the corresponding geometric and physical-mechanical characteristics.

In Table 8, we presented the data used for calculations relating to $\varnothing 48.3 \times 2.6 \mathrm{~mm}$ steel pipes, the pipelines being located on a street open to heavy road traffic, the pipe being filled with water, in a ground with underground water. 
Table 7. Steel pipes [40-43].

\begin{tabular}{|c|c|c|c|c|c|c|c|}
\hline No. & $\begin{array}{l}\text { Outer Diameter } \\
(\mathrm{mm})\end{array}$ & $\begin{array}{l}\text { Wall Thickness } \\
\text { (mm) }\end{array}$ & $\begin{array}{c}\text { Elastic Modulus } \\
\text { E (MPa) }\end{array}$ & $\begin{array}{c}\text { Shear Modulus } \\
\text { G (MPa) }\end{array}$ & $\begin{array}{l}\text { Poisson's } \\
\text { Ratio } \mu\end{array}$ & $\begin{array}{c}\text { Specific Weight } \\
\left(\mathrm{kN} / \mathrm{m}^{3}\right)\end{array}$ & $\begin{array}{l}\text { Yield Point } \\
\text { (MPa) }\end{array}$ \\
\hline 1 & 48.3 & 2.6 & 210,000 & 80,800 & 0.30 & 78.5 & 235 \\
\hline 2 & 88.9 & 3.2 & 210,000 & 80,800 & 0.30 & 78.5 & 235 \\
\hline 4 & 168.3 & 5.0 & 210,000 & 80,800 & 0.30 & 78.5 & 235 \\
\hline 5 & 244.5 & 6.3 & 210,000 & 80,800 & 0.30 & 78.5 & 235 \\
\hline 6 & 323.9 & 8.0 & 210,000 & 80,800 & 0.30 & 78.5 & 235 \\
\hline 8 & 508 & 10.0 & 210,000 & 80,800 & 0.30 & 78.5 & 235 \\
\hline 9 & 610 & 12.5 & 210,000 & 80,800 & 0.30 & 78.5 & 235 \\
\hline
\end{tabular}

Table 8. Action assessment—characteristic values for $\varnothing 48.3 \times 2.6 \mathrm{~mm}$ steel pipe.

\begin{tabular}{|c|c|c|c|c|}
\hline No. & Description & Symbol & Value & M.U. \\
\hline 1 & Uniformly distributed pressure-standard semi-axle & $\mathrm{p}_{0}$ & 625 & $\mathrm{kN} / \mathrm{m}^{2}$ \\
\hline 2 & Indentation width & 1 & 0.303 & $\mathrm{~m}$ \\
\hline 3 & Pipe coverage thickness & $\mathrm{H}$ & 0.3 & $\mathrm{~m}$ \\
\hline 4 & Width of distributed indentation & $\mathrm{L}$ & 0.903 & $\mathrm{~m}$ \\
\hline 5 & Pipe outer diameter & $\mathrm{D}$ & 0.0483 & $\mathrm{~m}$ \\
\hline 6 & Overload volume weight & $\gamma$ & 23 & $\mathrm{kN} / \mathrm{m}^{3}$ \\
\hline 7 & Internal friction angle & $\varnothing$ & 21.7 & $\circ$ \\
\hline 8 & Cohesion & $\mathrm{c}$ & 3.3 & $\mathrm{kPa}$ \\
\hline 9 & Active compression ratio & $\mathrm{ka}$ & 0.461 & \\
\hline 10 & Filler volumetric weight & $\gamma_{0}$ & 19 & $\mathrm{kN} / \mathrm{m}^{3}$ \\
\hline 11 & Internal friction angle & $\varnothing_{0}$ & 25 & $\circ$ \\
\hline 12 & Cohesion & $\mathrm{c}_{0}$ & 0 & $\mathrm{kPa}$ \\
\hline 13 & Passive compression ratio & $\mathrm{kp}_{0}$ & 2.464 & \\
\hline 14 & Uniformly distributed pressure & $\mathrm{pvH}$ & 70.37 & $\mathrm{kN} / \mathrm{m}^{2}$ \\
\hline 15 & Uniformly distributed loading_-standard semi-axle & pv1 & 63.5 & $\mathrm{kN} / \mathrm{m}$ \\
\hline 16 & Overload & pv2 & 6.9 & $\mathrm{kN} / \mathrm{m}$ \\
\hline 17 & Total vertical loadings & pv & 70 & $\mathrm{kN} / \mathrm{m}$ \\
\hline 18 & Upper earth compression & pah1 & -1.35 & $\mathrm{kN} / \mathrm{m}^{2}$ \\
\hline 19 & Lower earth compression & pah2 & 18.28 & $\mathrm{kN} / \mathrm{m}^{2}$ \\
\hline 20 & Earth compression & Pah1 & 0.0 & $\mathrm{kN} / \mathrm{m}$ \\
\hline 21 & Earth compression & Pah2 & 0.4 & $\mathrm{kN} / \mathrm{m}$ \\
\hline 22 & Earth compression-overload & Pah & 9.2 & $\mathrm{kN} / \mathrm{m}$ \\
\hline 23 & Earth compression-total & Pah, total & 9.6 & $\mathrm{kN} / \mathrm{m}$ \\
\hline 24 & Water volumetric weight & $\gamma \mathrm{w}$ & 10 & $\mathrm{kN} / \mathrm{m}^{3}$ \\
\hline 25 & Porosity & $\mathrm{n}$ & 0.33 & \\
\hline 26 & Volumetric weight of the solid filler framework & $\gamma \mathrm{s}$ & 26 & $\mathrm{kN} / \mathrm{m}^{3}$ \\
\hline 27 & Volumetric weight of the filler in submersed water conditions & $\gamma_{0}^{\prime}$ & 10.72 & $\mathrm{kN} / \mathrm{m}^{3}$ \\
\hline
\end{tabular}

In Table 8:

- $\quad$ lines 6-8 refers to overlay;

- lines 10-12 refers to earth around the pipe;

- lines 18-23 refers to lateral earth pressure.

The data are entered in a similar way for the other types of pipes.

The results of the calculations for the steel pipes are presented in Table 9.

According to the results presented in Table 9, in the case of steel pipes mounted under roads subject to heavy traffic, the following conclusions can be drawn:

- $\quad 48.3 \times 2.6 \mathrm{~mm}$ pipes and $88.9 \times 3.2 \mathrm{~mm}$ pipes have inappropriate behaviour when placed under roads subject to heavy traffic;

- $\quad 114.3 \times 4 \mathrm{~mm}$ pipes behave properly when placed under roads subject to heavy traffic, if they are placed underneath filler earth with heights ranging from $0.9 \mathrm{~m}$ to $2 \mathrm{~m}$;

- $\quad 168.3 \times 5 \mathrm{~mm}$ pipes behave properly when placed under roads subject to heavy traffic, if they are placed underneath filler earth with heights ranging from $0.3 \mathrm{~m}$ to $6 \mathrm{~m}$;

- $\quad 244.5 \times 6.3 \mathrm{~mm}$ pipes, $323.9 \times 8 \mathrm{~mm}$ pipes, $406 \times 8 \mathrm{~mm}$ pipes, $508 \times 10 \mathrm{~mm}$ pipes and $610 \times 12.5$ $\mathrm{mm}$ pipes behave properly when placed under roads subject to heavy traffic. 
Table 9. Results of the calculations for steel pipes.

\begin{tabular}{|c|c|c|c|c|c|c|c|c|c|c|}
\hline \multirow{3}{*}{ No. } & \multirow{3}{*}{$\begin{array}{c}\text { Coverage } \\
\text { Thickness (m) }\end{array}$} & \multicolumn{9}{|c|}{ Steel Pipes (A = Accepted/N = Not Recommended) } \\
\hline & & \multicolumn{9}{|c|}{ Dimensions (mm) } \\
\hline & & $48.3 \times 2.6$ & $88.9 \times 3.2$ & $114.3 \times 4$ & $168.3 \times 5$ & $244.5 \times 6.3$ & $323.9 \times 8$ & $406 \times 8$ & $508 \times 10$ & $610 \times 12.5$ \\
\hline 2 & 0.40 & $\mathrm{~N}$ & $\mathrm{~N}$ & $\mathrm{~N}$ & A & $\mathrm{A}$ & $\mathrm{A}$ & A & A & A \\
\hline 3 & 0.50 & $\mathrm{~N}$ & $\mathrm{~N}$ & $\mathrm{~N}$ & A & A & A & A & A & A \\
\hline 4 & 0.60 & $\mathrm{~N}$ & $\mathrm{~N}$ & $\mathrm{~N}$ & $\mathrm{~A}$ & A & A & A & A & A \\
\hline 7 & 0.90 & $\mathrm{~N}$ & $\mathrm{~N}$ & A & A & A & A & A & A & A \\
\hline 8 & 1.00 & $\mathrm{~N}$ & $\mathrm{~N}$ & A & A & A & A & A & A & A \\
\hline 9 & 1.10 & $\mathrm{~N}$ & $\mathrm{~N}$ & A & A & A & A & A & A & A \\
\hline 10 & 1.20 & $\mathrm{~N}$ & $\mathrm{~N}$ & A & A & A & A & A & A & A \\
\hline 11 & 1.30 & $\mathrm{~N}$ & $\mathrm{~N}$ & A & A & A & A & A & A & A \\
\hline 12 & 1.40 & $\mathrm{~N}$ & $\mathrm{~N}$ & A & A & A & A & A & A & A \\
\hline 13 & 1.50 & $\mathrm{~N}$ & $\mathrm{~N}$ & A & A & A & A & A & A & A \\
\hline 18 & 2.00 & $\mathrm{~N}$ & $\mathrm{~N}$ & A & A & A & A & A & A & A \\
\hline 19 & 3.00 & $\mathrm{~N}$ & $\mathrm{~N}$ & $\mathrm{~N}$ & A & A & A & A & A & A \\
\hline 20 & 4.00 & $\mathrm{~N}$ & $\mathrm{~N}$ & $\mathrm{~N}$ & A & A & A & A & A & A \\
\hline 21 & 5.00 & $\mathrm{~N}$ & $\mathrm{~N}$ & $\mathrm{~N}$ & A & A & A & A & A & A \\
\hline 22 & 6.00 & $\mathrm{~N}$ & $\mathrm{~N}$ & $\mathrm{~N}$ & A & A & A & A & A & A \\
\hline 23 & 7.00 & $\mathrm{~N}$ & $\mathrm{~N}$ & $\mathrm{~N}$ & $\mathrm{~N}$ & A & A & A & A & A \\
\hline 24 & 8.00 & $\mathrm{~N}$ & $\mathrm{~N}$ & $\mathrm{~N}$ & $\mathrm{~N}$ & A & A & A & A & A \\
\hline
\end{tabular}

The meaning of the notations used in Table 9 are the following:

- $\mathrm{A}=$ accepted; the calculations carried out show that the pipes are resistant to road traffic stresses;

- $\quad \mathrm{N}=$ not recommended; the calculations carried out show that the pipes are not resistant to road traffic stresses.

\subsubsection{Cast Iron Pipes}

The resistance calculation for cast iron pipes was made for both gray cast iron pipes and ductile cast iron pipes. The round pipe types presented in Tables 10 and 11 with the corresponding geometric and physical-mechanical characteristics were considered. The results of the calculations for the cast iron pipes are presented in Table 12.

Table 10. Gray cast iron pipes [44,45].

\begin{tabular}{|c|c|c|c|c|c|c|c|}
\hline No. & $\begin{array}{l}\text { Outer Diameter } \\
(\mathrm{mm})\end{array}$ & $\begin{array}{c}\text { Wall Thickness } \\
\text { (mm) }\end{array}$ & $\begin{array}{c}\text { Elastic Modulus } \\
\text { E (MPa) }\end{array}$ & $\begin{array}{c}\text { Shear Modulus } \\
\text { G (MPa) }\end{array}$ & $\begin{array}{l}\text { Poisson's } \\
\text { Ratio } \mu\end{array}$ & $\begin{array}{c}\text { Specific Weight } \\
\left(\mathrm{kN} / \mathrm{m}^{3}\right)\end{array}$ & $\begin{array}{l}\text { Yield Point } \\
\text { (MPa) }\end{array}$ \\
\hline 1 & 222 & 11.0 & 110,000 & 44,700 & 0.23 & 70.5 & 130 \\
\hline 2 & 428 & 14.0 & 110,000 & 44,700 & 0.23 & 70.5 & 130 \\
\hline 4 & 841 & 20.5 & 110,000 & 44,700 & 0.23 & 70.5 & 130 \\
\hline 5 & 1048 & 24.0 & 110,000 & 44,700 & 0.23 & 70.5 & 130 \\
\hline
\end{tabular}

Table 11. Ductile cast iron pipes [46,47].

\begin{tabular}{|c|c|c|c|c|c|c|c|}
\hline No. & $\begin{array}{l}\text { Outer Diameter } \\
(\mathrm{mm})\end{array}$ & $\begin{array}{l}\text { Wall Thickness } \\
\text { (mm) }\end{array}$ & $\begin{array}{c}\text { Elastic Modulus } \\
\text { E (MPa) }\end{array}$ & $\begin{array}{c}\text { Shear Modulus } \\
\text { G (MPa) }\end{array}$ & $\begin{array}{l}\text { Poisson's } \\
\text { Ratio } \mu\end{array}$ & $\begin{array}{c}\text { Specific Weight } \\
\left(\mathrm{kN} / \mathrm{m}^{3}\right)\end{array}$ & $\begin{array}{l}\text { Yield Point } \\
\text { (MPa) }\end{array}$ \\
\hline 1 & 222 & 11.0 & 170,000 & 69,100 & 0.23 & 70.5 & 200 \\
\hline 2 & 428 & 14.0 & 170,000 & 69,100 & 0.23 & 70.5 & 200 \\
\hline 4 & 841 & 20.5 & 170,000 & 69,100 & 0.23 & 70.5 & 200 \\
\hline 5 & 1048 & 24.0 & 170,000 & 69,100 & 0.23 & 70.5 & 200 \\
\hline
\end{tabular}


Table 12. Results of the calculations for the cast iron pipes.

\begin{tabular}{ccccccc}
\hline & & \multicolumn{5}{c}{ Gray/Ductile Cast Iron Pipes (A = Accepted/N = Not Recommended) } \\
\cline { 3 - 7 } No. & $\begin{array}{c}\text { Coverage } \\
\text { Thickness (m) }\end{array}$ & \multicolumn{5}{c}{ Dimensions (mm) } \\
\cline { 3 - 7 } & & $\mathbf{2 2 2} \times \mathbf{1 1}$ & $\mathbf{4 2 8} \times \mathbf{1 4}$ & $\mathbf{6 3 4} \times \mathbf{1 7}$ & $\mathbf{8 4 1} \times \mathbf{2 0 . 5}$ & $\mathbf{1 0 4 8} \times \mathbf{2 4}$ \\
\hline 1 & 0.30 & $\mathrm{~A}$ & $\mathrm{~A}$ & $\mathrm{~A}$ & $\mathrm{~A}$ & $\mathrm{~A}$ \\
2 & 0.40 & $\mathrm{~A}$ & $\mathrm{~A}$ & $\mathrm{~A}$ & $\mathrm{~A}$ & $\mathrm{~A}$ \\
3 & 0.50 & $\mathrm{~A}$ & $\mathrm{~A}$ & $\mathrm{~A}$ & $\mathrm{~A}$ & $\mathrm{~A}$ \\
4 & 0.60 & $\mathrm{~A}$ & $\mathrm{~A}$ & $\mathrm{~A}$ & $\mathrm{~A}$ & $\mathrm{~A}$ \\
5 & 0.70 & $\mathrm{~A}$ & $\mathrm{~A}$ & $\mathrm{~A}$ & $\mathrm{~A}$ & $\mathrm{~A}$ \\
6 & 0.80 & $\mathrm{~A}$ & $\mathrm{~A}$ & $\mathrm{~A}$ & $\mathrm{~A}$ & $\mathrm{~A}$ \\
7 & 0.90 & $\mathrm{~A}$ & $\mathrm{~A}$ & $\mathrm{~A}$ & $\mathrm{~A}$ & $\mathrm{~A}$ \\
8 & 1.00 & $\mathrm{~A}$ & $\mathrm{~A}$ & $\mathrm{~A}$ & $\mathrm{~A}$ & $\mathrm{~A}$ \\
9 & 1.10 & $\mathrm{~A}$ & $\mathrm{~A}$ & $\mathrm{~A}$ & $\mathrm{~A}$ & $\mathrm{~A}$ \\
10 & 1.20 & $\mathrm{~A}$ & $\mathrm{~A}$ & $\mathrm{~A}$ & $\mathrm{~A}$ & $\mathrm{~A}$ \\
11 & 1.30 & $\mathrm{~A}$ & $\mathrm{~A}$ & $\mathrm{~A}$ & $\mathrm{~A}$ & $\mathrm{~A}$ \\
12 & 1.40 & $\mathrm{~A}$ & $\mathrm{~A}$ & $\mathrm{~A}$ & $\mathrm{~A}$ & $\mathrm{~A}$ \\
13 & 1.50 & $\mathrm{~A}$ & $\mathrm{~A}$ & $\mathrm{~A}$ & $\mathrm{~A}$ & $\mathrm{~A}$ \\
14 & 1.60 & $\mathrm{~A}$ & $\mathrm{~A}$ & $\mathrm{~A}$ & $\mathrm{~A}$ & $\mathrm{~A}$ \\
15 & 1.70 & $\mathrm{~A}$ & $\mathrm{~A}$ & $\mathrm{~A}$ & $\mathrm{~A}$ & $\mathrm{~A}$ \\
16 & 1.80 & $\mathrm{~A}$ & $\mathrm{~A}$ & $\mathrm{~A}$ & $\mathrm{~A}$ & $\mathrm{~A}$ \\
17 & 1.90 & $\mathrm{~A}$ & $\mathrm{~A}$ & $\mathrm{~A}$ & $\mathrm{~A}$ & $\mathrm{~A}$ \\
18 & 2.00 & $\mathrm{~A}$ & $\mathrm{~A}$ & $\mathrm{~A}$ & $\mathrm{~A}$ & $\mathrm{~A}$ \\
19 & 3.00 & $\mathrm{~A}$ & $\mathrm{~A}$ & $\mathrm{~A}$ & $\mathrm{~A}$ & $\mathrm{~A}$ \\
20 & 4.00 & $\mathrm{~A}$ & $\mathrm{~A}$ & $\mathrm{~A}$ & $\mathrm{~A}$ & $\mathrm{~A}$ \\
21 & 5.00 & $\mathrm{~A}$ & $\mathrm{~A}$ & $\mathrm{~A}$ & $\mathrm{~A}$ & $\mathrm{~A}$ \\
22 & 6.00 & $\mathrm{~A}$ & $\mathrm{~A}$ & $\mathrm{~A}$ & $\mathrm{~A}$ & $\mathrm{~A}$ \\
23 & 7.00 & $\mathrm{~A}$ & $\mathrm{~A}$ & $\mathrm{~A}$ & $\mathrm{~A}$ & $\mathrm{~A}$ \\
24 & 8.00 & $\mathrm{~A}$ & $\mathrm{~A}$ & $\mathrm{~A}$ & $\mathrm{~A}$ & $\mathrm{~A}$ \\
\hline
\end{tabular}

According to the results presented in Table 12, the cast iron pipes of $222 \times 11 \mathrm{~mm}, 428 \times 14 \mathrm{~mm}$, $634 \times 17 \mathrm{~mm}, 841 \times 20.5 \mathrm{~mm}$ and $1048 \times 24 \mathrm{~mm}$ mounted under roads subject to heavy traffic behaved properly.

\subsubsection{High Density Polyethylene (HDPE) Pipes}

The resistance calculation for high density polyethylene (HDPE) pipes was made considering the pipe types presented in Table 13 with the corresponding geometric and physical-mechanical characteristics.

Table 13. HDPE pipes [48].

\begin{tabular}{|c|c|c|c|c|c|c|c|}
\hline No. & $\begin{array}{l}\text { Outer Diameter } \\
(\mathrm{mm})\end{array}$ & $\begin{array}{l}\text { Wall Thickness } \\
\text { (mm) }\end{array}$ & $\begin{array}{c}\text { Elastic Modulus } \\
\text { E (MPa) }\end{array}$ & $\begin{array}{c}\text { Shear Modulus } \\
\text { G (MPa) }\end{array}$ & $\begin{array}{l}\text { Poisson's } \\
\text { Ratio } \mu\end{array}$ & $\begin{array}{c}\text { Specific Weight } \\
\left(\mathrm{kN} / \mathrm{m}^{3}\right)\end{array}$ & $\begin{array}{l}\text { Yield Point } \\
\text { (MPa) }\end{array}$ \\
\hline 1 & 20 & 2.0 & 700 & 310 & 0.42 & 9.5 & 25 \\
\hline 2 & 40 & 2.4 & 700 & 310 & 0.42 & 9.5 & 25 \\
\hline 4 & 110 & 6.6 & 700 & 310 & 0.42 & 9.5 & 25 \\
\hline 5 & 160 & 9.5 & 700 & 310 & 0.42 & 9.5 & 25 \\
\hline 6 & 200 & 11.9 & 700 & 310 & 0.42 & 9.5 & 25 \\
\hline 9 & 400 & 23.7 & 700 & 310 & 0.42 & 9.5 & 25 \\
\hline
\end{tabular}

The results of the calculations for the HDPE pipes are presented in Table 14. 
Table 14. Results of the calculations for the HDPE pipes.

\begin{tabular}{|c|c|c|c|c|c|c|c|c|c|c|}
\hline \multirow{3}{*}{ No. } & \multirow{3}{*}{$\begin{array}{c}\text { Coverage } \\
\text { Thickness } \\
\text { (m) }\end{array}$} & \multicolumn{9}{|c|}{ HDPE Pipes (A = Accepted/N = Not Recommended) } \\
\hline & & \multicolumn{9}{|c|}{ Dimensions (mm) } \\
\hline & & $20 \times 2$ & $40 \times 2.4$ & $75 \times 4.5$ & $110 \times 6.6$ & $160 \times 9.5$ & $200 \times 11.9$ & $250 \times 14.8$ & $315 \times 18.7$ & $400 \times 23.7$ \\
\hline 2 & 0.40 & $\mathrm{~N}$ & $\mathrm{~N}$ & $\mathrm{~N}$ & $\mathrm{~N}$ & $\mathrm{~N}$ & $\mathrm{~N}$ & $\mathrm{~N}$ & A & A \\
\hline 3 & 0.50 & $\mathrm{~N}$ & $\mathrm{~N}$ & $\mathrm{~N}$ & $\mathrm{~N}$ & $\mathrm{~N}$ & $\mathrm{~N}$ & $\mathrm{~N}$ & A & A \\
\hline 4 & 0.60 & $\mathrm{~N}$ & $\mathrm{~N}$ & $\mathrm{~N}$ & $\mathrm{~N}$ & $\mathrm{~N}$ & $\mathrm{~N}$ & A & A & A \\
\hline 7 & 0.90 & $\mathrm{~N}$ & $\mathrm{~N}$ & $\mathrm{~N}$ & $\mathrm{~N}$ & $\mathrm{~N}$ & $\mathrm{~N}$ & A & A & A \\
\hline 8 & 1.00 & $\mathrm{~N}$ & $\mathrm{~N}$ & $\mathrm{~N}$ & $\mathrm{~N}$ & $\mathrm{~N}$ & $\mathrm{~N}$ & A & A & $\mathrm{A}$ \\
\hline 9 & 1.10 & $\mathrm{~N}$ & $\mathrm{~N}$ & $\mathrm{~N}$ & $\mathrm{~N}$ & $\mathrm{~N}$ & $\mathrm{~N}$ & A & A & A \\
\hline 10 & 1.20 & $\mathrm{~N}$ & $\mathrm{~N}$ & $\mathrm{~N}$ & $\mathrm{~N}$ & $\mathrm{~N}$ & $\mathrm{~N}$ & A & A & A \\
\hline 11 & 1.30 & $\mathrm{~N}$ & $\mathrm{~N}$ & $\mathrm{~N}$ & $\mathrm{~N}$ & $\mathrm{~N}$ & $\mathrm{~N}$ & A & A & A \\
\hline 12 & 1.40 & $\mathrm{~N}$ & $\mathrm{~N}$ & $\mathrm{~N}$ & $\mathrm{~N}$ & $\mathrm{~N}$ & $\mathrm{~N}$ & A & A & A \\
\hline 17 & 1.90 & $\mathrm{~N}$ & $\mathrm{~N}$ & $\mathrm{~N}$ & $\mathrm{~N}$ & $\mathrm{~N}$ & $\mathrm{~N}$ & A & A & A \\
\hline 18 & 2.00 & $\mathrm{~N}$ & $\mathrm{~N}$ & $\mathrm{~N}$ & $\mathrm{~N}$ & $\mathrm{~N}$ & $\mathrm{~N}$ & A & A & A \\
\hline 19 & 3.00 & $\mathrm{~N}$ & $\mathrm{~N}$ & $\mathrm{~N}$ & $\mathrm{~N}$ & $\mathrm{~N}$ & $\mathrm{~N}$ & $\mathrm{~N}$ & A & A \\
\hline 20 & 4.00 & $\mathrm{~N}$ & $\mathrm{~N}$ & $\mathrm{~N}$ & $\mathrm{~N}$ & $\mathrm{~N}$ & $\mathrm{~N}$ & $\mathrm{~N}$ & A & A \\
\hline 21 & 5.00 & $\mathrm{~N}$ & $\mathrm{~N}$ & $\mathrm{~N}$ & $\mathrm{~N}$ & $\mathrm{~N}$ & $\mathrm{~N}$ & $\mathrm{~N}$ & A & A \\
\hline 22 & 6.00 & $\mathrm{~N}$ & $\mathrm{~N}$ & $\mathrm{~N}$ & $\mathrm{~N}$ & $\mathrm{~N}$ & $\mathrm{~N}$ & $\mathrm{~N}$ & $\mathrm{~N}$ & A \\
\hline 23 & 7.00 & $\mathrm{~N}$ & $\mathrm{~N}$ & $\mathrm{~N}$ & $\mathrm{~N}$ & $\mathrm{~N}$ & $\mathrm{~N}$ & $\mathrm{~N}$ & $\mathrm{~N}$ & A \\
\hline 24 & 8.00 & $\mathrm{~N}$ & $\mathrm{~N}$ & $\mathrm{~N}$ & $\mathrm{~N}$ & $\mathrm{~N}$ & $\mathrm{~N}$ & $\mathrm{~N}$ & $\mathrm{~N}$ & A \\
\hline
\end{tabular}

According to the results presented in Table 14, in the case of high density polyethylene (HDPE) pipes mounted under roads subject to heavy traffic, the following conclusions can be drawn:

- $\quad 20 \times 2 \mathrm{~mm}, 40 \times 2.4 \mathrm{~mm}, 75 \times 4.5 \mathrm{~mm}, 110 \times 6.6 \mathrm{~mm}, 160 \times 9.5 \mathrm{~mm}$ and $200 \times 11.9 \mathrm{~mm}$ pipes behave inappropriately when placed under roads subject to heavy traffic;

- $250 \times 14.8 \mathrm{~mm}$ pipes behave properly when placed under roads subject to heavy traffic, if they are placed underneath filler earth with heights ranging from $0.6 \mathrm{~m}$ to $2 \mathrm{~m}$;

- $\quad 315 \times 18.7 \mathrm{~mm}$ pipes behave properly when placed under roads subject to heavy traffic, if they are placed underneath filler earth with heights ranging from $0.3 \mathrm{~m}$ to $5 \mathrm{~m}$;

- $\quad 400 \times 23.7 \mathrm{~mm}$ pipes behave properly when placed under roads subject to heavy traffic.

\subsection{Discussions}

Analysing the results of the calculations, it is noticed that heavy road traffic primarily affects pipes having a small nominal diameter, namely pipes having a nominal diameter of up to $300 \mathrm{~mm}$.

Also, for the analysed case study, namely the water supply system of the city of Cluj-Napoca in Romania, it was found out that out of the total number of failures, more than $95 \%$ were related to the water connecting pipes and distribution pipes.

As pipes have to satisfy both hydraulic requirements and road traffic resistance requirements simultaneously, we recommend that in the case of pipes with a nominal diameter of less than $300 \mathrm{~mm}$, the resistance to road traffic loading should also be checked. Obviously, if the pipes do not withstand the load of the road traffic, then for the same nominal pipe diameter we can choose a pipe with a thicker wall, so that it can withstand the load of the road traffic.

The selection of pipes with a larger wall thickness leads to a reduction in pipe section and obviously to increased pressure losses. As a result of increased pressure losses, it may be necessary for some pipe sections to choose larger diameter pipes.

Analysing the failures that occurred in the water supply system of the city of Cluj-Napoca, it should be noted that the failures due to road traffic occur as a rule:

- $\quad$ on streets with intense road traffic; 
- $\quad$ on streets where heavy road traffic has been deviated;

- $\quad$ on the roads where road repair works have been carried out;

- on old piping sections.

Failures to the water supply systems of localities due to the unfavourable influence of road traffic lead to higher pipeline repair costs, increased water losses, and water losses can also determine damages to other utility networks.

In this context, we recommend that in the Romanian technical regulations regarding the design, operation and rehabilitation of water supply systems, to introduce the obligation to analyze the influence of road traffic on the water supply system pipelines. This obvious analysis can be made on the basis of analytical calculations as presented in this paper, either by submitting documents from pipeline manufacturers with regard to the minimum and the maximum mounting depths at which pipelines can be fitted, depending on the type of material and depending on the loads resulting from road traffic.

We recommend that technical regulations in Romania should also comprise the obligation that, besides the technical expertise of the roads, the technical expertise of water networks, sewerage networks, methane gas networks and heating networks be conducted in the following cases:

- $\quad$ on the streets where heavy traffic is to be deviated;

- on the streets where road repair and modernization works will be carried out.

Following the expertise of utility networks, a number of conclusions can be drawn, for example:

- the maximum tonnage of the means of transport that will be able to travel on a certain street;

- the determination of the working technology for road infrastructure rehabilitation, namely the type of construction equipment to be used, the weight of the construction equipment, and the type of means of transport to be used;

- the need to replace utility networks along with the modernization of roads;

- the protection measures that need to be taken to protect utility networks.

Applying these measures will ultimately lead to:

- a reduction in the number of failures of utility networks;

- a reduction in the cost of repairs to utility networks;

- $\quad$ an increase in the safety of the utility networks;

- a reduction in the water losses related to the drinkable water distribution system in the localities.

Although the case study has been conducted for heavy road traffic conditions in Romania, Autodesk Robot Structural Analysis Professional 2011 software allows changing the calculation hypotheses so that calculations can be made for other road traffic loads as well as for different materials used for building the water distribution networks.

\section{Conclusions}

Based on this study, it is found that street road traffic exerts a certain influence on the constituents of the water distribution networks, depending on the building materials and the geometric configurations of the constituents, capable of generating defects of the water distribution networks. Therefore, preventive measures are recommended to avoid such situations.

Based on the results obtained from the analytical calculation, we noticed that heavy road traffic primarily affects the pipes with a small nominal diameter, i.e., pipes with a nominal diameter of up to $300 \mathrm{~mm}$. In this context, we recommend that for pipelines with a nominal diameter of up to $300 \mathrm{~mm}$ located on roads with heavy road traffic, to carry out a verification of the strength of these pipelines for loads caused by heavy road traffic. 
Obviously, if the pipes do not withstand the load of the road traffic, than for the same nominal pipe diameter we can choose a pipe with a thicker wall, so that it can withstand the load of the road traffic. The selection of pipes with a larger wall thickness leads to a reduction in pipe section and obviously to increased pressure losses. As a result of increased pressure losses, it may be necessary for some pipe sections to be necessary to choose larger diameter pipes.

The results of the research are useful in the design phase of water distribution networks, so depending on the type of pipe material, the minimum mounting depth can be indicated, so as to avoid the failure of the pipes due to road traffic.

The proposed method leads to the avoidance of failures in water distribution networks due to the unfavourable action of road traffic, so this method is a proactive method that is preferable to the reactive practice of rehabilitation of water distribution networks, i.e., after a failure.

During the phase of water distribution networks exploitation, the areas where street traffic can lead to water pipeline network failures can be established.

From this perspective, we are considering writing an article on the effect of dynamic loads and vibrations due to heavy road traffic on water distribution networks.

In the future, similar studies could also be conducted, regarding the negative influence of road traffic on sewerage networks, gas networks and thermal networks.

Author Contributions: Conceptualization, I.A.; Formal analysis, N.C.; Methodology, M.I.; Writing-review \& editing, I.G. All authors read and approved the final version of the manuscript.

Funding: This research received no external funding.

Acknowledgments: The authors acknowledge with satisfaction the valuable suggestions made by anonymous reviewers to an earlier version of this paper which have helped transform this version into a better one.

Conflicts of Interest: authors declare no conflict of interest.

\section{References}

1. Chaallal, O.; Arockiasamy, M.; Godat, A. Field test performance of buried flexible pipes under live truck loads. J. Perform. Constr. Facil. 2014, 20, 04014124-1-04014124-10. [CrossRef]

2. Al-Barqawi, H.; Zayed, T. Infrastructure management: Integrated AHP/ANN model to evaluate municipal water mains' performance. J. Infrastruct. Syst. 2008, 14, 305-318. [CrossRef]

3. Al-Aghbar, A. Automated Selection of Trenchless Technology for Rehabilitation of Water Mains. Master's Thesis, Concordia University, Montreal, QC, Canada, 2005.

4. Rakitin, B.; Xu, M. Centrifuge modeling of large-diameter underground pipes subjected to heavy traffic loads. Can. Geotech. J. 2014, 51, 353-368. [CrossRef]

5. Xu, M.; Shen, D.; Rakitin, B. The longitudinal response of buried large-diameter reinforced concrete pipeline with gasketed bell-and-spigot joints subjected to traffic loading. Tunn. Undergr. Space Technol. 2017, 64, 117-132. [CrossRef]

6. Li, S.; Wang, R.; Wu, W.; Sun, J.; Jing, Y. Non-hydraulic factors analysis of pipe burst in water distribution systems. Procedia Eng. 2015, 119, 53-62. [CrossRef]

7. Alzabeebee, S.; Chapman, D.; Jefferson, I.; Faramarzi, A. The response of buried pipes to UK standard traffic loading. Proc. Inst. Civ. Eng. Geotech. Eng. 2017, 170, 38-50. [CrossRef]

8. British Standards Institution. BS 9295:2010 Guide to the Structural Design of Buried Pipelines; British Standards Institution: London, UK, 2010.

9. Rajeev, P.; Kodikara, J.; Robert, D.; Zeman, P.; Rajani, B. Factors contributing to large diameter water pipe failure. Water Asset Manag. Int. 2014, 14, 9-14.

10. Pîslărașu, I.; Rotaru, N.; Teodorescu, M. Water Supply, 2nd ed.; Editura Tehnică: Bucharest, Romania, 1970; p. 307. (In Romanian)

11. Luleh va Mashinsazi Iran. Ductile Cast Iron Pipes. Available online: http://www.lmico.net/userfiles/file/ DN100-2000-\%20ISO\%202531-2009.pdf (accessed on 24 July 2018). 
12. Aşchilean, I. Theoretical and Experimental Contributions Regarding the Rehabilitation and Modernization of Urban Water Supply. Ph.D. Thesis, Technical University of Cluj-Napoca, Cluj-Napoca, Romania, 2010. (In Romanian)

13. Asschilean, I.; Iliescu, M.; Ciont, N. The Unfavorable Impact of Street Traffic on Water Pipes, Sewage and Gas Solutions and Ways of Solving; Technical University of Cluj-Napoca: Cluj-Napoca, Romania, 2013; pp. $13-14$. (In Romanian)

14. Așchilean, I. Rehabilitation and Modernization of the Water Supply Systems of Towns; Editura Risoprint: Cluj-Napoca, Romania, 2014; pp. 149-155. ISBN 978-973-53-1212-1. (In Romanian)

15. Guidelines on the Rehabilitation of Pipes Used for Water Distribution; Code GP 127-2014; Ministry of Regional Development and Public Administration: Bucharest, Romania, 2014; pp. 7, 13-18. (In Romanian)

16. Așchilean, I.; Badea, G.; Giurca, I.; Naghiu, G.S.; Iloaie, F.G. Determining priorities concerning water distribution network rehabilitation. Energy Procedia 2017, 112, 27-34. [CrossRef]

17. Așchilean, I.; Giurca, I. Choosing the water distribution pipe rehabilitation solution using the ANP method. Water 2018, 10, 484. [CrossRef]

18. Ancaș, A.D.; Profire, M.; Cojocaru, G. Experimental evaluation a tensile strength of PAFSIN pipes in different types of land. J. Appl. Eng. Sci. 2017, 7, 11-16. [CrossRef]

19. Ancaș, D.A.; Profire, M.; Verdeș, M.; Ciocan, V. Dynamic analysis of the seismic action of underground structure to water transport. Rev. Romana De Ing. Civila 2017, 8, 238-242. (In Romanian)

20. Asschilean, I.; Badea, G.; Giurca, I.; Naghiu, G.S.; Iloaie, F.G. Choosing the optimal technology to rehabilitate the pipes in water distribution systems using the AHP method. Energy Procedia 2017, 112, 19-26. [CrossRef]

21. Coufal, M.; Vaclavik, V.; Dvorsky, T.; Bendova, M. Rehabilitation of asbestos cement water mains for potable water in the Czech Republic. In Proceedings of the 14th International Multidisciplinary Scientific GeoConference SGEM 2014, Albena, Bulgaria, 19-25 June 2014; SGEM: Sofia, Bulgaria, 2014; Volume 1, pp. 579-586.

22. Gao, Y. Systematic Review for Water Network Failure Models and Cases. Master's Thesis, Wuhan University of Technology, Wuhan, China, 2014.

23. Giurconiu, M.; Mirel, I.; Carabeț, A.; Chivereanu, D.; Florescu, C.; Stăniloiu, C. Water and Wastewater Constructions and Facilities; Editura de Vest Timişoara: Timişoara, Romania, 2002; pp. 126-143. ISBN 973-36-0357-0. (In Romanian)

24. Calos, S.; Contaşel, M.A.; Balmuş, L. Water Distribution Networks; Combinatul Poligrafic: Chişinău, Republic of Moldova, 2004; pp. 94-133. ISBN 9975-9820-5-0. (In Romanian)

25. Jacobs Engineering; San Diego County Water Authority, Engineering Department. ESD 160 Design Manual. Volume Two: Facility Design Guide; Jacobs Engineering: San Diego, CA, USA, 2007; pp. 2-7-2-14.

26. Van Zyl, J.E. Introduction to Operation and Maintenance of Water Distribution Systems, 1st ed.; Water Research Commission: Gezina, Republic of South Africa, 2014; pp. 61-69. ISBN 978-1-4312-0556-1.

27. Saadeh, M.; Beck, S.; Ngwenya, K.; Chen, D. Optimal Design of Water Distribution System to Minimize Risk of Water Main Breaks in Western Fort Wayne. Senior Design I; Department of Engineering, Indiana University-Purdue University Fort Wayne: Fort Wayne, IN, USA, 2013; pp. 11-16.

28. Mohamed, E.; Zayed, T. Funding infrastructure renewal plan for water distribution system. In Proceedings of the Annual Conference of the Canadian Society for Civil Engineering 2008, Québec, QC, Canada, 10-13 June 2008; Volume 1, pp. 62-72.

29. Asociaţia Română a Apei; Consiliul Tehnico-Ştiinţific. 2009 Technology Stage Report; Water Supply and Sewage Systems, Expo Apa: Bucharest, Romania, 2009. (In Romanian)

30. Asociatia de Standardizare din România (ASRO). SR 4032-1:2001 Road Works. Terminology; ASRO: Bucharest, Romania, 2001. (In Romanian)

31. Asociatia de Standardizare din România (ASRO). STAS 10144/1-90 Cross-Sectional Profiles. Design Requirements; ASRO: Bucharest, Romania, 1990. (In Romanian)

32. Asociatia de Standardizare din România (ASRO). STAS 10144/3-91 Geometrical Elements. Design Requirements; ASRO: Bucharest, Romania, 1991. (In Romanian)

33. Advanced Structural Analysis Software. Available online: http://www.autodesk.com/products/robotstructural-analysis/overview (accessed on 18 April 2018).

34. Simão, M.; Mora-Rodriguez, J.; Ramos, H.M. Design Criteria for Suspended Pipelines Based on Structural Analysis. Water 2016, 8, 256. [CrossRef] 
35. European Commission, Directorate General Transport. COST 333. Development of New Bituminous Pavement Design Method. Final Report of the Action; Office for Official Publications of the European Communities: Luxembourg, Belgium, 1999; pp. 173-184. ISBN 92-828-6796-X.

36. Romanian normative. PD 177-2001 Normative for Dimensioning of Slender and Semi-Rigid Road Systems-Analytical Method; Romania Ministry of Public Works: Bucharest, Romania, 2001. (In Romanian)

37. Burmister, D.M. The General Theory of Stresses and Displacements in Layered Systems. J. Appl. Phys. 1945, 16,89-94. [CrossRef]

38. The European Union. EN 1991-1-1 Eurocode 1: Actions on Structures; The European Union: Brussels, Belgium, 1991.

39. The European Union. EN 1990 Eurocode-Basis of Structural Design; The European Union: Brussels, Belgium, 1990.

40. International Organization for Standardization. ISO 559:1991 Steel Tubes for Water and Sewage; ISO: Geneva, Switzerland, 1991.

41. British Standards Institution; The European Union. BS EN 10217-1:2002 Welded Steel Tubes for Pressure Purposes. Technical Delivery Conditions. Part 1: Non-alloy Steel Tubes with Specified Room Temperature Properties; British Standards Institution: London, UK; The European Union: Brussels, Belgium, 2002.

42. British Standards Institution; The European Union. BS EN 10224:2002 Non-alloy Steel Tubes and Fittings for the Conveyance of Water and Other Aqueous Liquids. Technical Delivery Conditions; British Standards Institution: London, UK; The European Union: Brussels, Belgium, 2002.

43. British Standards Institution; The European Union. BS EN 10255:2004 Non-alloy Steel Tubes Suitable for Welding and Threading. Technical Delivery Conditions; British Standards Institution: London, UK; The European Union: Brussels, Belgium, 2004.

44. International Organization for Standardization. ISO 185: 2005 Grey Cast Iron-Classification; ISO: Geneva, Switzerland, 2005.

45. British Standards Institution; The European Union. BS EN 1561:2011 Founding. Grey Cast Irons; British Standards Institution: London, UK; The European Union: Brussels, Belgium, 2011.

46. British Standards Institution; The European Union. BS EN 545:2010 Ductile Iron Pipes, Fittings, Accessories and Their Joints for Water Pipelines-Requirements and Test Methods; British Standards Institution: London, UK; The European Union: Brussels, Belgium, 2010.

47. International Organization for Standardization. ISO 2531:2009 Ductile Iron Pipes, Fittings, Accessories and Their Joints for Water Pipelines; ISO: Geneva, Switzerland, 2009.

48. International Organization for Standardization. ISO 4427-2:2007 Plastics Piping Systems_Polyethylene (PE) Pipes and Fittings for Water Supply_Part 2: Pipes; ISO: Geneva, Switzerland, 2007. 